\title{
Canadian Refugee Services: The Challenges of Network Operations
}

\begin{abstract}
The context within which refugee service providers work shapes and constrains their efforts. Those legal,political,fiscal, and managerial influences in the Canadian context have tended to force the creation of refugee service networks. This article considers some of the factors that have brought about this network approach to refugee service delivery, but, most importantly, it seeks to understand what the implications of that development are for service providers and the communities they serve. This articleargues that servicenetworks can be effective and efficient in meeting refugee needs, but it isessential to be aware of the special challenges posed by network management. Those challenges not only concern how service providers work together and deal with refugees and otherimmigrants, but also alert them to the impact they can have inside refugee service NGOs.
\end{abstract}

\section{Résumé}

Le contexte dans lequel les prestataires de services aux réfugiés travaillent, façonne et restreint leurs efforts. Ces influences légales, politiques, fiscales et administratives dans le contexte canadien, ont eu tendance à pousser vers la création de réseaux de services aux réfugiés. Cet article étudie certains des facteurs qui ont amené cette approche de prestation de services aux réfugiés par réseau. Mais, avant tout, il cherche à comprendre quelles sont les implications de ce développement pour, d'une part, les prestataires de services et, del'autre, pour les communautés qu'ils servent. L'article soutient que les réseaux de services peuvent être utiles et efficaces pour répondre aux besoins des réfugiés, mais $q u ' i l$ faut absolument être conscient des défis particuliers que comportela gestion de ces réseaux. Ces défis ne concernent pas seulement la façon dont les prestataires de services travaillent de

Phillip J. Cooper is a Gund Professor of Liberal Arts at the University of Vermont.

\author{
Phillip J. Cooper
}

concert et s'occupent des réfugiés et d'autres immigrés. Il est aussi important d'être vigilant quant à l'impact qu'ils peuvent avoir au sein des ONG spécialisées dans les services aux réfugiés.

\section{Introduction}

Those of us who study refugee issues come to Canada to learn. For many years, Canadians have taught other nations a great deal by their willingness toopen theirdoors to refugees and their generosity in seeking to provide services for them as the new arrivals become full members of the Canadian society. Thecreativity of the refugee servicecommunity in Canada has provided innovative and effective models for organizations and programmes that can better assist refugees as well other new Canadians. The dedicated corps of people, many of them whom were refugees and immigrants themselves, has demonstrated to the rest of us how energy and commitment can make a dramatic difference in the people we all ultimately seek to serve the larger society. These are among the reasons why the Canadian people were collectively awarded the Nansen Medal (named after Fridtjof Nansen, the first High Commissioner for Refugees under the League of Nations) for service to refugees. This was the first time an entire nation was honoured.

Of course, in light of all that, when challengesemergein the Canadian refugee policy and service delivery system, the rest of us should be concerned and seek to learn from the way those challenges are met. It is also important to understand the impact of the decisions that are taken within Canada, for just as it has been a leader in so many aspects of refugee service, the situation in Canada serves as a warning to others of what lies in the horizon of this field.

The challenge of providing refugee services rests in part, as the other arti- cles in this symposium demonstrate, on the level of professional practice - the state of the art in refugee service delivery. But no matter how creative, how expert, or how professional the service providers may be, their ability to successfully deliver support for refugees who arrive in Canada depends, as it does in other countries, upon a variety of issues that they do not control. The context within which service providers and the refugee families they seek to assist must live and work matters. The legal, political, fiscal and management challenges presented by the environment in which the refugee challenge mustbe metcalls upon the very best that dedicated professionals can deliver. Yet they also place boundaries on what can be accomplished and the methods that can be used to achieve their goals on behalf of the people they serve.

An examination of those factors over the past decade in Canada indicates a number of important trends. One of the factors is the tendency for changing policy and resource constraints to alter the working relationships between government and nongovernmental organizations (NGOs) that provide refugee services and among those NGOs as well. In particular, these dynamics have tended to force the creation of refugee service networks. This article considers some of the factors that have brought about this change to a network approach in the refugee service delivery system, but most importantly, it seeks to understand what the implications of that development are for service providers and the communities they serve. Following these arguments that have been presented, the thesis that emerges is as follows: while service networks can be effective and efficient in meeting refugee needs, it is a kind of organization that requires a high degree of awareness of the special challenges posed by network management and a commit- 
ment of resources to meet those challenges. Among these challenges is the need to be alert to the impact they can have on the NGOs which are critical to the system and the differences that exist between network operations in the private for-profitbusiness community and the not-for-profit public service sector.

The discussion will turn first to the forces that are shaping the service networks. It will then consider the network concept in action. Finally, it will address the implications of the move to interdependent service networks.

\section{The Critical Forces Shaping Refugee Service Networks}

Canada has increasingly felt a number of forces that have been shaping refugee policy, the resources available to serve new arrivals and the context within which they and their service providers must liveand work. These are dynamics that have been building in many other countries, most notably the E.U. nations and the United States, even before some of the most recent changes in Canada. And while Canada remains steadfast in declaring its commitment to the humanitarian principles that have made it a world leader in this field, it would be unrealistic to suggest that these political, economic, and legal stresses have not brought increased stress to the effort to provide refugee services.

\section{Political Pressures to Emphasize Enforcement and Protection of Borders}

There is no doubt that the smuggling incidents in recent years havecaptured a great deal of attention. It was one thing when authorities apprehended small numbers of people attempting illegal entries at various border points. However, the situation took on a new and ominous quality when Canadian and U.S. officials found people in cargo containers at West Coast ports. This occurred shortly after the highly publicized cases in which Canadian agencies, civilian and military, were called in to track and then to deal with vessels, better described as hulks than as ships, carrying immigrants bound for British Columbia. Since these events began in the summer of 1999, Citizenship and Immigration Minister Elinor Caplan has been at pains to answer demands for more enforcement and stronger efforts to exclude illegal immigrants. ${ }^{1}$ Sadly, when such demands arise in Canada or elsewhere, the voices raising them are rarely sensitive to the distinctions between legitimate refugees who come by some troublesome means or others. That is particularly true if MPs and party officials see an opportunity for political gain in exploiting public fear and anger. It is all the more troublesome if such events are allowed to fuel already growing anti-immigrant sentiment. And although Caplan has stressed the government's intention to maintain its immigration target at $1 \%$ of population and its expectations for 25,000 refugee arrivals in 2000 , she has repeatedly found it necessary to respond to fears and frustrations.

I understand the concerns of many
Canadians about these recent marine
arrivals. I want to make it clear that
I deplore the actions of human smug-
glers. I am also deeply concerned
about the increasing number of peo-
ple who turn to the criminal element
in choosing to enter Canada surrep-
titiously and illegally....

Criminal actions such as these only confirm the need to change our legislation. Early this year, the government proposed new legislative directions on immigration and refugee policy. These directions include enhancing our ability to intercept illegal migrants abroad, stiffer penalties for those who contravene our laws, and the increased use of detention of people. ${ }^{2}$

These pressures have also meant that many government statements about refugees begin with a recognition of the importance of the immigrant community and the humanitarian commitment to assist refugees, but are frequently qualified. "Canadian are compassionate and generous. That has notchanged. But Canadians willnot be taken advan- tage of. This I can assure you." 3 "Our Government will continue to accept refugees, while at the same time take strong measures to stem the flow of those who try to abuse our refugee programme." "I want to keep the front door to this country open, but I know that to doso, we've got to make sure that we close the back door." 5

Much of Caplan's term has been spent addressing reactions to the illegal ships smuggling people in cargo container, but these high profile events did not mark the beginning of the reaction against refugees and immigrants. By the mid-1990s popular media outlets reported changing attitudes across Canada, and particularly in the West.

Clearly, Canada is not alone in facing such political pressures. Indeed, it is following trends that have been developing for some time in Europe and the United States. In these countries, the humanitarian focus for refugee policy has lost ground to the economic, foreign policy, and domestic politics foci and the general trend has been the attempt to view refugee issues as matters to be dealt with abroad, miles away from one's own country, if possible, or as border problems if necessary. ${ }^{6}$ This effort to shift both the focus and locus of refugee policy is clear despite longstanding commitments by these countries to the 1951 United Nations Convention Relating to the Status of Refugees $^{7}$ and the 1967 Protocol Relating to the Status of Refugees. ${ }^{8}$

There have been three obvious impacts that emerged from this trend. First, there has been atendency to discourage the movement of refugees to these countries. Second, policymak-ing has tended to emphasize a law enforcement effort aimed at blocking illegal immigrants in which refugees have come to be seen as another type of immigrant or removing those who seem to have slipped through the net. Third, this focus on borders and beyond, and the increasing importance of law enforcement has tended to support increased attention to resource needs for enforcement with decreasing concern for the needs of refugee service programmes. 


\section{The Economic Pressures Of Stressful Times, Market Pressures, and Declining Support for the Social Safety Net}

As witnessed around the world at other times and in many places, economics played a role in the growing tensions around refugee policy, including settlement services. Hard times often breed increases in scape-goating. Certainly, the United States provides a particularly glaring history of this kind of behaviour, but it is not the only place where refugees and other immigrants have been falsely accused of taking jobs away from natives. Of course, as Minister Caplan has reminded Canadians:

One reason for this tolerance and compassion is that we are a nation of immigrants and refugees. Consider that today, forty-six members of the House of Commons were born outside of Canada. Our new Governor General, Adrienne Clarkson, came to Canada as a refugee during the Second World War.

My grandparents were immigrants, and so were many of yours. Indeed, apart from our aboriginal population, ALL Canadians are descended from immigrants or refugees. It's really just a matter of seniority. ${ }^{9}$

But the anti-refugee and anti-immigrant sentiment predated the events that have taken Caplan's attention since she acquired her portfolio. The economic stresses of the 1980s and 1990s had two important consequences. First, they have played a role in a constrained but real reaction against generous refugee policies. In January 1993, MacClean's reported the results of a Maclean's / CTV survey, indicating that "regardless of age, income or level of education," four of five respondents considered increased immigration "'bad,' 'verybad' or simply'a fact of life." And, the report added that there was a clear connection between those attitudes and the state of the economy.

Thirty-two per cent of those who were pessimistic about the economy had negative opinions of visible minorities, while only 26 per cent of those who felt the economy was improving said that immigrants from Asia, the West Indies and other parts of the Third World were bad for Canada. ${ }^{10}$

Second, the dramatic economic cutback decisions taken by Ottawa in response to the economic challenges meant reduced support for a wide variety of social programmes, including those serving refugees and immigrants. The federal government dramatically cut a variety of programmes, including significant reductions in transfer payments to the provinces. So significant were the federal rollbacks that even a major effort in 1999 to put funds back into medical care through the Canada Health and Social Transfer (CHST) still did not restore transfer payments for these programmes to quite the level they had been despite the return of a better financial situation.

In the face of those cuts, provincial governments in turn trimmed many of their programmes and in some cases those provincial changes were even more drastic than the changes in Ottawa. Local school boards, like Ottawa/ Carleton debated resolutions to the provincial ministry asking for reconsideration of major cuts in special education and increasing restrictions on eligibility for English as a second language programmes, effectively cutting those programmes. In British Columbia, the Union of Municipalities published a study by an independent firm on the relationship between federal cuts to provinces and provincial cuts to municipalities. It found that by any measure, the cuts by the provinces were even more severe than the cuts from Ottawa.

In 1996, BC Municipalities received $\$ 209$ million in general fund transfer payments from the Province. This was cut to $\$ 129$ million in 1997 and 1998 as a result of the changes announced by the Province at the end of 1996. This is a $38 \%$ reduction in the level of transfer payments.

In December 1998, the Province announced a further reduction in municipal transfer payments of $\$ 39$ million, to be effective in 1999. This will reduce the general fund transfer payments to $\$ 90$ million. This is a further $30 \%$ reduction from the 1998 level. And it will be implemented in one year. ${ }^{11}$

In addition to these cuts in support for social programmes spending in the provinces and at the local government level, Ottawa cutbudgets in federalministries, including in Citizenship and Immigration Canada (CIC). Planned spending between 1998-99 and 2001-02 is scheduled to decline by $9.6 \%$ in nominal dollars while continuing work levels at approximately the same number of immigrants and refugees. If one assumes a very conservative $3 \%$ inflation figure, the real dollar impact would be more than $17.3 \%$ reduction over that same period. ${ }^{12}$ These cuts come at a time when CIC is asked to be more responsive, faster, and more active than ever before. Since this was written, funds were added to the CICbudgetbutlargely for enforcement.

And, of course, all of these cuts hit hardest those at the end of the financial pipeline, the refugees and the NGOs that provide their services. The Canadian Council for Refugees (CCR) summed up the situation as follows:

In recent years, the economic climate and the governments' deficit reduction priorities have had their impact on refugees, always among the most vulnerable when time comes for cut back. Newly arrived in Canada and with very limited resources, refugees and other immigrants have faced reduced services from the Immigration Department, cuts in social assistance and job training programmes, reduced medical coverage and legal aid coverage, increased fees in many areas .... Organizations offering services to refugees and immigrants have had to respond to these new difficulties faced by their clients, at the same time that they are themselves often suffering funding cutbacks. ${ }^{13}$

\section{A New and Even More Demanding Legal Context for Refugee Service Agencies}

The other element that has been dynamic and of major importance for refu- 
gee service agencies is the changing legal context. There have been two critical dimensions to the changes in this field. First, there have been the increasing demands for intensified enforcement efforts. Second, Canada has been in a major effort at policy change.

The earlier discussion of the response to the British Columbia events underscored the government's emphasis on enforcement and attempts to speed up resulting adjudications, leading to faster exclusions if they are deemed appropriate. The pressures to intensify these enforcement efforts were exacerbated by U.S. criticisms that $\mathrm{Ca}$ nadian policies and lax enforcement efforts had made it a haven for terrorists. Even Canadian voices have been heard supporting such charges. ${ }^{14}$

However, long before the recent pressures began building in order to tighten Canadian policy and practices for refugees and immigrants, the trend in that direction was well established. The pressures for change came both from within Canada and from developments in other countries.

International trends toward restricting asylum and speeding up exclusions of those whodo manage to enter borders have been underway for some time. Well before the Maastricht Treaty went into force, E.U. countries had been moving toward more restrictive refugee law and legal process. Ironically, the changing laws governing border control can be traced back to the time of the efforts by E.U. countries to open their borders to one another in order to ease commercial relations. The Netherlands, Luxembourg and Belgium began efforts toopen their borders to each other in 1960 . France and Germany entered into a similar agreement in 1984 and then joined their predecessors in an accord signed in Schengen, Luxembourg which have since come to be known as the Schengen Agreements. ${ }^{15}$ Eventually, over a dozen countries, some of which were E.U. nations and others, joined together in the Schengen Convention and the Schengen Implementation Agreement. Theseagreements involved cooperation on cross-border criminal justice concerns as well as information sharing and cooperation among police and judicial officials in the signatory countries. They also required harmonization of refugee policies to block what was termed asylum shopping. With this approach of 1992, the E.U. countries entered into the Dublin Convention in 1990 which incorporated most of the elements of the Schengen agreements and added new elements. Most recently, the effort to ratify and implement the terms of the Treaty of Amsterdam signed in 1997, promises for more E.U. institutional control over refugee policy.

Tomany refugees, Europe was erecting legal walls around itself. The E.U. countries served notice that they would invoke the first asylum principle and the safe country of origin doctrine not only to exclude claimants, but also to exclude applicants even before their petitions were resolved. ${ }^{16}$ The trend has also been to permit expedited determination procedures with fewer legal protections for asylum seekers and greater discretion for officials. The working party on asylum procedures of the International Association of Refugee Law Judges has examined the use of such procedures and found that while they may have the benefit of speed and efficiency, they pose serious risks that the rights of asylum seekers will be sacrificed in the bargain. ${ }^{17}$

The U.S. case also demonstrated similar trends. Although the United States was a major supporter of the 1951 Convention and the 1967 Protocol, it did not formally join these agreements until 1968 and did not adopt a comprehensive Refugee Act until 1980. ${ }^{18}$ Part of the original impetus for passage of the 1980 legislation came from the sad history of U.S. behaviour in Southeast Asia and the problems that emerged in dealing with refugees following the American pull-out. ${ }^{19}$

Butbefore the ink was dry on the new law, the U.S. was moving to restrictentry and discriminating among applicant groups on political and according to many critics, racial grounds. Tensions grew over the handling of Cuban and Haitian asylum seekers that were ultimately addressed not through legisla- tion, butby the executive orders issued by Presidents Reagan, Bush and Clinton. ${ }^{20}$ The U.S. government ultimately entered into a consent decree in the case of American Baptist Churches $v$. Thornburgh, ${ }^{21}$ effectively admitting discrimination in Central American asylum cases and agreeing to reconsider virtually all Salvadoran and Guatemalan asylum applicants during the period. In 1996, a new immigration statute was adopted that granted much greater discretion to Immigration and Naturalization Service officers. It provided for expedited summary asylum determinations at the border with little or no judicial review ${ }^{22}$ Even the U.S. Justice Department declined to implement some of the more extreme provisions of the statute and to provide more protections than were required. ${ }^{23}$ At this point, the best that can be said is that the U.S. had gone back to the ad hoc approach to refugees that existed decades ago. Not surprisingly, the laws and practices adopted by the European nations and the U.S. have sent signals that the doors are closed in these locations, thus making Canada an even more attractive destination than ever before.

However, Canada has moved in the same direction as its American and European allies. The contemporary line of policy development can be traced back to the late 1980 s when Immigration Minister Barbara McDougall announced a major move to tighten the system, including efforts to speed up the status determination process and clear a large backlog of pending cases. It was this round of policymaking that produced C-55 in 1989 and resulted in the creation of the Immigration and Refugee Board (IRB). Then came C-86 in 1992 which further trimmed the hearing process and constrained appeals. These measures were intended not only to streamlinebut also to restrict refugee admissions and the percentage of approvals did fall, according to the then IRBGeneralCounsel GeraldStobo, from $76 \%$ in 1989 to $48 \%$ by late $1993 .{ }^{24}$ Citizenship and Immigration Canada was created in 1994 and efforts have been made since then to reevaluate and replace the existing citizenship law. 
Minister Lucienne Robillard appointed a Legislative Review Advisory Group inNovember of 1996 to review the existing Immigration Act. Its January 1998 report, entitled Not Just Numbers: $A$ Canadian Framework for Future Immigration, ${ }^{25}$ included 172 recommendations. After a year of consultation and planning, CIC issued its white paper Building on $a$ Strong Foundation for the 21st Century: Directions for Immigration and Refugee Policy and Legislation. ${ }^{26}$ Several things were clear. First, the government had heard complaints about the need to reduce delays in the refugee status determination process, calls regarding the need for greater attention to family reunification and demands that provisions be enacted that would permitCIC to respond toemergency situations abroad that called for rapid removal to Canada of threatened persons. At the same time, there is no doubt that enforcement had become the central feature of the new policymaking efforts. Whatever themotive forces, as the white paper pointed out: "No comprehensive review of the legislation has been undertaken during the past two decades. The Act has been amended, on an ad hoc basis, more than 30 times, resulting in a complex patchwork of legislative provisions that lack coherence and transparency. The logic and key principles of the Act have become difficult to discern for both immigrants and Canadians." 27 Indeed, the government eventually tabled a comprehensive legislative proposal to rewrite the Citizenship Act in November 1999 known as C-16 that embodied the concerns noted above.

It became clear from the report and in the proposed legislation that enforcement and the emphasis on exclusion of unworthy claimants are dominant themes. Thus, for example, while the chapter of the white paper entitled "Refugee Protection" presents two issues that are associated with added protections for refugees, the other six highlighted issues that had to do with enforcement and exclusion of unqualified applicants. ${ }^{28}$ The other chapters reveal a similar emphasis, as do the Minister's speeches throughout the fall of 1999 and into the beginning of $2000 .{ }^{29}$ Her speeches emphasize that the government's approach can be summa- rized in three words: Faster, but fair. Or as PeterShowler, the current Immigration and Refugee Board Chair, has putit: Fair, butfaster. ${ }^{30}$ Onemightsuggest that the order of the words matters more than a little. From the perspective of the refugee claimant, it is fine to reduce the waiting time for decisions and to speed up family reunification. On the other hand, moves such as increasing pressure for greater identity documentation at entry, expanding the use of detention, speeding up the hearing and decision process, streamlining review processes, and tightening judicial review suggest that the "faster" is likely to prevail over the "fair." That was, as noted above, precisely what the International Association of Refugee Law Judges concluded has been happening based upon an examination of the expedited procedures now in use in a number of countries. The new provisions of the Citizenship Act proposed as C-16 not only move to implement some of these streamlining suggestions, but also grant new authority to revoke citizenship (Sec. 16), block citizenship on broad assertions of public interest (Sec. 21) or national security interest (Sec. 23) by the Minister. It also expands the list of those ineligible to apply for citizenship (Sec. 28). Since this was written the new refugee law C-31 has been tabled as well.

It must be said that even with all these steps, Canada has not moved nearly as dramatically toblock or challenge asylum seekers as the U.S. or the E.U. Even so, there can be little doubt about the general direction of the efforts to change the law and the process by which it is administered in an enforcementmodewith the emphasis on protecting the nation against criminal smuggling of persons, detecting and rapidly excluding illegitimate attempts to claim refugee status and building the legal capacity to apprehend and remove anyone perceived to have made it through the process but who later is determined to have been undesirable.

At a minimum, these processes in Canada, the U.S. and Europe, place a premium on the ability of newly arrived refugee claimants to be fully ready to make their legal claim, assume knowledge of the requirements for doing so and in truth demand rapid access to legal assistance. However, these expectations come at a time when legal aid has been limited. Moreover, with increasingly stringent requirements to qualify for services in some provinces, service providers require greater legal counselling in order to assist their clients.

The Move to Service Networks From Multiple Loosely Coupled Organizations: A Transformation More Real Than Apparent

These legal, financial, and political changes have all had significant effects not only on refugees and refugee claimants but also on the organizations that seek to serve them. One of the results of these increasingly challenging features of the refugee service environment has been an increasing pressure, often unspoken, to alter the structure and character of refugee service delivery from a relatively loosely coupled collection of largely independent organizations toward a highly stressed service network. It is therefore extremely important to consider the general trend in human services toward the service network model, the realities of network management and the implications of life in a highly stressed servicenetworkfor refugee services.

For some time, NGOs were created and evolved relatively independently. Many grew from small groups that came together, often with some or most of their members as volunteers. Others developed from church or civil groups that decided to develop a project group to sponsor or work with refugees. Still, others emerged from refugee and immigrant communities themselves as those whohad been in Canada long enough to feel settled themselves tried to help others who were facing the same daunting experience.

These groups became important parts of a service system made up of loosely coupled organizations, many of which focused on very different kinds of 
clients, needs and services. Many of the programmes they provided developed because of needs recognized in the schools, by medical practitioners, police agencies, child welfare officials, or employment and economic development stakeholders. Their missions varied dramatically and their funding and organization were equally diverse. In some cases, they formed relatively simple partnerships with these agencies, involving pilot programmes or modest service agreements.

However, as service demands increased and resources declined, pressures grew not only concerning how to meet new levels of service demand but also about survival itself. Pressures grew to compete more vigorously for grants and contracts. However, that often meant making one's organization look more and more like what the requests for proposals seek. As groups scrambled to look more like the fewer funding sources desired, it appeared as though there was more redundancy, a justification for further reductions. Given the fact that much of the soft money had relatively brief funding cycles, the scrambling became less of a sporadic activity than an ongoing challenge. It also meant that organizations had to consider more carefully what they could and could not deliver. From the government perspective, there has been greater pressure to eliminate redundancy, enhance efficiency and ensure greater accountability. Given these conditions, pressures and expectations, the tendency has been to move, deliberately or de facto, toward a network model of service delivery with a variety of significant consequences for all concerned.

\section{The Critical Realities of Network Management}

There was a time when citizens often looked to Governments to provide services directly. However, the range of service demands, constraints on the size of ministries and agencies and a desire for a variety of approaches to service delivery led to a growing tendency of governments to form relationships, often termed public/private partnerships, to support the missions of the various
NGOs and local government agencies that actually delivered the services. Still, the relationships were often relatively loose and informal, in part at least to allow room for the not-for-profits to use their creativity and special knowledge without undue bureaucratic baggage from government. If there was a service gap, these organizations were often able to locate resources, modest though they may have been, to pick up theslack. And, since the NGO workers and volunteers were so often very committed people, they dig deep to find innovative solutions to the service issues in new ways to build trust, better communications with local agencies like police, school principals, or health care providers and more effective mechanisms for eliciting involvement by parents and others in the immigrant communities who have so much to offer. Indeed, it was in this way that some groups began to expand their operations and build their organizations. NGOs sought to remain relatively informal and loosely coupled both in terms of their internal operations and their relationships to other service providers. Management was often not regarded as particularly important, for decision making processes remaining, to one degree or another, essentially collaborative.

As financial, political, legal demands and pressures mounted, the need for all attention to management has grown. Service organizations have found themselves competing for available grants and contracts. Unfortunately, each new funding arrangement has brought new obligations that have added more stress. The irony was that at the same time that service providers saw themselves in one way or another as competitors, they were also becoming more and more interdependent and governments were becoming more interdependent with these service providers as well ${ }^{31}$ Government could not provide directly the required services. Few NGOs possessed the slack resources to fill in gaps if other service providers failed or terminated programmes. No longer could governments, federal or provincial, think in terms of simple partnerships, a concept that conjures up a picture of two parties deciding to cooperate for a discrete purpose. Refugee services had become a network and given the increasing interdependencies among the participants, it could not be considered loosely coupled.

\section{What is a Service Network and Why Does It Matter?}

There is more involved in the rise of service networks than accidents of political and economic history. Popularized by international corporate operations, the idea of network operations has been to achieve maximum efficiency and minimum capitalization requirements by creating networks to produce and market a product or service rather than creating a single organization to do thejob. It is also referred to in some settings as the concept of the "hollow corporation" 32 or in a more recent manifestation "the virtual corporation." 33

One of the earlier and most commonly cited examples is Nike, the athletic shoe company. ${ }^{34}$ The idea is that a company contracts with a firm in one country to make the shoes, with another to handle distribution, another to do marketing, and others to provide other necessary services. In such a network, one must manage not only each of the organizations in the network, sometimes referred to as nodes, but also the linkages among the nodes as well. If any unit in the network breaks down or if any of the relationships among units is blocked or fails, then the network manager must find a way to fill the gap and repair the system. Thus, the network is based on mutual interdependencies. The issue is not just the needs of the firm whose logogoes on the product, but the interests of all of the other participants in the process as well. The shoe manufacturer is dependent not only on the corporation that purchased the shoes for its product line, but the distributors, marketers, and others without whose contribution the buyer will fail and be unable to pay for the product or buy more. Hence the maintenance of the critical linkages among the units as well as the skills that the managers have within each of the units are essential to 
the success of the entire network and all of those who participate in it.

The advantages of networks seemed to be that they allow the organization that seeks a network operation two important options. First and most important for many firms, is that this mode of operation allows the networkbuilder to shed costs, both operational and capital. The network is built with a series of contracts with each of the other units in the network. Each contractor is responsible for its own plant and equipment. More than that, it is responsible for the recruitment, training, management and compensation of its people. Indeed, even where a firm had capabilities inhouse, executives often chose to spin those units off into separate businesses to shed costs and manage responsibilities. Taken far enough, this allows an organization to trim its costs to theminimum by slimming down internally to perform only those functions that could not be contracted out. Hence the firm was enhancing its own productivity and efficiency by retaining and consuming only those resources absolutely necessary to its operation. The efficiencies for the other units in the system are achieved by using the marketplace to control contractor costs. This of course assumes the existence of a competitive market in whatever goods or services required.

The second advantage cited by advocates for network operations is flexibility. At its best, the network relies upon all its units to use their creativity to address problems as they arise, as opposed to an integrated organization that must find solutions for all problems that come through the doors. If the contractors are unable to meet the new challenges, then one could simply drop that contractor and enter into an agreement with a new one. Supply and demand would presumably generate new potential contractors with the necessary capabilities and with employees possessing the needed skill sets to deal with the changing environment.

The public sector counterpart of these developments is what has been referred to as the "Hollow Government" pushed by politicians around the world bent on cutting the size of government ministries and budgets, privatizing to the greatest degreepossible and employing as many private sector management tools as possible. ${ }^{35}$ And these moves were supported by advocates of what has been termed the New Public Management. ${ }^{36}$ Although contracting out for goods and services was an important part of governance for many years, it dramatically expanded during the 1980 s and 1990 s to the point where governments have become dependent upon not-for-profit and for-profit organizations to deliver most of its services and in which governments no longer have the capability of delivering any significant portion of many of the services it is mandated to make available. ${ }^{37}$ The hope was that these public servicenetworks would bring the same kinds of benefits as their private sector counterparts.

\section{Caution! Network Management Is Different}

However, some of the early advocates for network operations failed to recognize some of the challenges that such an approach entailed. Even those in the private sector found that the model posed "real risks," including the loss of control, dependence upon other organizations that might "drop the ball," the danger that a firm could become involved with organizations that could tarnish its reputation, the need to share sensitive information and themore complex the entanglements of the network, the more likely it is that participating units might "stumble." 38 Above all, the networkmode of operation meant "new challenges for management. "39

If the operation of tight networks posed difficulties for private sector groups, itmeant even morecomplicated challenges for public service organizations. Looking back on early experiences with network efforts, Agranoff and McGuire concluded:

One realization is becoming increasingly clear: the capacities required to operate successfully in network settings are different from the capabilities needed to succeed at managing a single organization. The classical, mostly intra-organizational inspired management perspective that has guided public administration for more than a century is simply inapplicable for multi-organizational, multi-governmental, and multisectoral forms of governing. ${ }^{40}$

And they added that "there aremany more questions than answers in networkmanagement." ${ }^{41}$ In addition to the planning, organizing, staffing, budgeting and other traditional functions within their own organizations, managers in networks must also be engaged in such specialized activities as "activation,", "framing," "mobilizing," and "synthesizing." 42 At a minimum, it is essential to recognize the level of sophistication and capabilities necessary to networkmanagement. However, many of the organizations involved in networks do not even have really effective contract management capabilities, let alone the more sophisticated requirements of networkmanagement. Building that kind of capability not only means assigning people now attending to direct service or direct supervision to new tasks, but requires the development of new skills or the hiring of people with the kinds of specialized knowledge necessary to meet the evolving challenges posed by network operations.

There are other challenges that are more complex for the public sector networks as well. Since the programmes involved are sometimes mandated services for needy clients, network failures mean that someone must be able to step in rapidly. Where government does not have the capability to do that, it must be able to find alternate providers, which is not always easy. For one thing, there may be important controls to be satisfied concerning access to and use of confidential client information, particularly where children or health care issues are involved as is common in refugee services.

Of course, the ability to take advantage of the claimed flexibility of networks requires that there be multiple suppliers available. However, as networks become tighter and more interdependent (some might say more efficient) there are often relative few alternates 
available. This is one of the reasons that those who have studied the matter have found that networks work best in resource rich environments, not the other way around..$^{43}$ Resource poor environments can increase competition among some network participants which, in turn, can undermine the levels of trust that are so essential to the effective operation of the network. Unfortunately, it has generally been the case in Canada in recent years that public service networks are anything but resource rich.

Clearly, networks in the public service arena, particularly in the world of refugee services, are very different from for-profit private sector networks. For one thing, they must respond to values other than economicefficiency and their success cannot be measured by profits. In addition to efficiency, public sector operations must meet obligations of economy, effectiveness, equity, responsiveness and responsibility.

Moreover, the people who provide the human resources that are at the very core of refugee service delivery are in a very different situation from private sector employees. Many refugee service organizations depend upon volunteer programmes to provide important elements of their programmes and also as a recruitment device for futureemployees. Development and operation of such volunteer programmes requires significant investment of time and energy because volunteer work is a concept that is not well known in many other countries. Employees may be paid, but they are often expected to provide far more hours and effort than a similaremployee in a private firm. They are expected to do multiple duty in both direct service delivery and also in organizational maintenance and support. Moreover, they are expected to devote a significant amount of time and effort to participation in community programmes and projects within the immigrant and refugee communities they serve. All of thesechallenges shape the notion of leadership and management of the refugee service agencies, the other agencies, local governments and ministries that depend upon them, complex and challenging.
Leaders are stressed to spend more time on boundary spanning and fundraising at a time when the stresses within their organizations require more hands-on effort. If those within the organization or their board of directors feel that management and leadership are no longer attentive to concerns at the point of service and within their organization, that situation can fuel tension and even conflict within these NGOs. ${ }^{44}$

These are only some of the reasons why public service networks are more complex than their private sector analogs. With these differences in mind, let us turn to some of the more specific implications of increasing pressure to move into tightly interdependent service networks in the area of refugee services.

\section{The Implications of Networks for Refugee Services}

There are a number of implications that flow from the trends discussed thus far. The discussion of networkissues to this point or the more pointed observations to follow are not intended to say that the idea of networks should be abandoned or that efforts should not be made to ensure that refugee service systems should be less than efficient. After all, there are increasing demands and decreasing resources to provide critically important services. And it is unlikely that we will move backward to a time of relatively autonomous organizations operating in loosely coupled partnerships. It is, however, necessary that we come to grips with what is required to lead and operate service networks. It is also important not to push the network model too far in ways that do not recognize the differences between the private, for-profitmodel and the realities of refugee service delivery in the public arena that is not about profit that is not solely concerned with efficiency.

The following preliminary observations about refugee servicenetworks are notmeant tobeexhaustive. Rather, they are intended to indicate why it is important for all those who participate in refugee services to think further about the realities of life in the network. These illustrative issues include the impor- tance of networks by design and not accident, the importance of capacity building for all participants, the challenges of governance of the network, the need to address resources in the network, the critical importance of accountability and the internal impacts on NGO service providers in the network.

\section{Networks as Deliberate Choices}

If government wants to have refugee services provided by a network instead of a group of loosely coupled NGO partners, that decision is best made forthrightly and should not be the result of uncontrolled policy drift. On the one hand, such networks cannot work well if the approach to their management is merely to seek to turn NGOs into standard units of ministries. The strength of refugee service organizations in Canada is that they are very different in nature, function and operation. On the other hand, the structure of networks and the processes by which they function matter. ${ }^{45}$ At some point, it becomes important for all of the participants in the service networks to understand what the networks are, who is in the network, how it is structured and what formal or informal understandings guide the operation of the network.

In some instances, of course, the networks are relatively formal and are established in part at least by legislation, regulations, grants, or contracts. In other instances, they are much more informal. For example, while police departments are often not formally part of a network that centres on school based programmes, law enforcement agencies can often be helpful to or problematic for the refugee community in a variety of ways. The object of attempting to be clear in understanding networks is not to formalize them to the point where they lose their flexibility, but to ensure that it is clear that there is a network and to be clear how it works, or for that matter does not work.

Of course, if the networks are to be understood and their operation supported, the focus of effortmust be clear. It is unlikely that the network chal- 
lenges can be met and the basic goals of refugee services can be achieved if the focus on decision making is shifted primarily to law enforcement concerns such as efforts to block immigrantsmuggling or illegal refugee claims. If the refugee networks become confused about the primary purpose, and focus only on stamping out ailments in the system, they may succeed in curing the disease only to have killed or seriously weakened the patient, the larger society that has benefited so much from the strength, intelligence, and creativity contributed by refugees and other new arrivals.

\section{Capacity Building: An Essential Element for Ensuring Effective Service Network Operations}

If the object is to create and rely upon a network to provide public services, then it is essential to consciously determine who will provide the resources for network maintenance and the management capabilities to ensure its effectiveness. It is in everyone's best interest to ensure that all of the units participating in the network have the requisite capabilities. In relatively tightly linked networks with high levels of interdependency, the entire network is only as strong as its weakest component.

In particular, there are several factors that require attention in capacity building for network operations. First, public service networkmanagementrequires a fairly high degree of sophistication. In the first place, the backbone of most networks is a set of contracts or grants in the nature of contracts. Few organizations will claim that they have substantial contract management capabilities. Beyond that, while each participant in the networkmustmanage its own internal operations, each must also participate in the management of the network and networks are subject to a host of uncertainties and contingencies. ${ }^{46}$

The resources to build the capacity to function in networks must come from somewhere. While associations of provider organizations can support some of the work, it is clear that governments must accept responsibility for a significant part of the capacity building effort. Just as the government must provide resources for network management, so do ministries, both federal and provincialmust be provided with the types and amounts of resources needed to perform their roles. It is not possible to push more demands and large amounts of resources through ministries that have been cut to the point where they no longer have the capacity to perform their base functions, let alone new obligations. The first casualty of that kind of behaviour is decreasing support from those ministries to the NGOs for the delivery of services. The second will be loss of accountability.

\section{Governance is a Critical Fact of Life: Whether It is Recognized as Such or Not}

Attention must also be paid to the governance of such networks. As Milward puts it:

The fact that a hollow state relies on networks is a weakness as well as a strength. . Networks, the mainstay of the hollow state, are inherently weaker forms of social action. Because of the need to coordinate joint production, networks are inherently unstable over time. Managers continually are faced with problems that can lead to instability negotiating, coordinating, monitoring, holding third parties accountable and writing and enforcing contracts ...47

Networksdo not respond well to simple overhead controls. Besides, thecreativity and drive that make NGOs such constructive partners for the provision of public services can easily be lost if they are not afforded an active role in the governance of the network.

All this having been said, there are power relationships among the units of a network and not simply from government toNGOs. Those who have studied the matter find that governance issues relating to power are often overlooked because it is assumed that the very idea of networks implies mutual cooperation and the assumption that special interests are to be "checked at the door. ${ }^{48}$ However, anyone who has participated in meetings involving schools, refugee service agencies, provincial authorities and city officials knows that the representatives of each of these organizations come to the meeting with a sense of his or her specific mission and of the interests of the organization each represents in addition to their common concern for the needs of refugees.

While thelessons of the private sector networks may be of some assistance, such issues as accountability and the critical importance of high levels of trust between clients and service providers make the refugee service context very different. Among other reasons, the kinds of incentive systems that are often used to manage private operations are very different from the public setting. For all these reasons, it is important to consider how the networks in which one operates is governed. That means not only a consideration of cooperative efforts, but also a willingness to consider what happens when conflicts arise. It also requires thought about the kinds of issues that each of the participants in the refugee service network brings to the table.

\section{The Nagging Problem of Resource Scarcity and Interdependence}

One of the serious problems facing refugee service networks is the difficulty of resource shortages amidst increasing demands for services. The kinds of cuts in federal funding, in transfer payments to the provinces and reductions in support at the provincial level for local service providers and local units of government have presented precisely the kinds of circumstances, that those who study networks suggest, are counterproductive. They arecounterproductive in part because they provide incentives for NGOs to compete with one another for resources in the form of more limited number of grants and contracts. Moreover, where the funds for existing grants or contracts are reduced, providers are faced with a need to seek a larger number of grants or contracts to yield the same level of funding, which is essential if those organizations are to be 
able to support their paid staff and their operations. Of course, each of those grants or contracts comes with administrative costs and reporting obligations as well as the need to perform the specific activities set forth in the funding agreement. Thus, the NGO is leveraged toproduce more for the same amount of funding or less. Not only that, but the organization must find a way to release officers to do the additional work on the funding applications as well as administration of the additional programmes if the applications are successful.

There is the additional problem that the issue of resources in a network context is not simply a question of the resources available to a particular service provider organization. It also has to do with the cumulative resources available to the network. Thus, the dramatic reductions in funds from the provincial level in British Columbia to municipalities primarily affects police and fire agencies. That, in turn, means that there are fewer training dollars and less time available for programmes that refugee groups would like to operate with those emergency services units. Similarly, the issue of resources in Ontario includes educational funding cuts, changes in English as a Second Language (ESL) programme eligibility that in effect are programme cuts and the crisis in the health care programmes, as well as restrictions on access to certain kinds of benefit programmes for applicants at certain stages of the refugee claimant process. All of these funding issues affect, for example, multicultural liaison officers based in the schools.

The ironic fact is that a reduction in available services can intensify the pressures within refugee families and ultimately produce greater demand if the family moves into crisis or if the children begin to manifest behavioural difficulties in school or even find themselves in trouble with law enforcement authorities. It is important to consider not only the resource base of a particular unit of a network, but also the general resource picture of the network relative to its responsibilities and the population it is expected to serve. Another irony arises from the fact that re- source needs are increased when an enforcement oriented emphasis is undertaken, since it requires more application materials and more record keeping to ensure that applicants are truly qualified to receive the services and to protect against misuse of the system. Hence, the costs of service delivery in the network increase for the same level of services.

Of course, one of these network-wide resource issues has to do with the problem of network management. For reasons noted earlier, successful network operations require capacity building. That capacity must include the wherewithal to conduct network governance, to carry out essential coordination and buffering among network units. Then there is the need for the capacity in the network to handle accountability concerns which become increasingly complex in network operations.

\section{The Accountability Challenge}

Virtuallyeveryone whohasstudied networks agrees that accountability in such settings is particularly difficult. There are several reasons. For one thing, it has been argued that "The leakage of accountability in the hollow state and the lack of government capability or willingness to effectively manage its contracts with nonprofits is a major problem." ${ }^{49}$ This issue of "leakage" is a concept popularized by Bardach and Lesser who argue that the fact the "leakage of authority" that occurs when networks are created and operated collaboratively offers flexibility, but it also makes accountability much more complex. ${ }^{50}$ Because authority and responsibility are parcelled out within the network, it is difficult to get a clear picture of how well the network is performing as well as the effectiveness of individual units within the network. The NGOs within the network are accountable not to only the governments and private funding agencies at all levels who provide resources, but also to their boards of directors, to the other member units of the network and ultimately to the refugees and their families for whom the entire system was created in the first place. The ministries, in turn, face other accountability requirements for the operation of the network, as the recent debates over the operation of Human Resources Development Canada indicate.

With regard to ministries, one of the problems is that the nature of discussions of accountability within the context of the New Public Management have become more complex generally, quite apart from the additional issues presented by service delivery networks. It is clear that while ministerial responsibility is a very positive concept that is central to Canadian democracy, there seem to have been changes in the way that this traditional mechanism of accountability operates in the contemporary environment. ${ }^{51}$ Beyond that there has been an increasing tendency in Canada to employ legal tools of accountability. It is ironic that during the very period when Canadians were increasingly using the courts to test government policy and behaviour, efforts havebeen made to restrict access by refugee claimants and other new arrivals to call upon the courts for substantive judicial review. In the midst of this set of dynamics, administrative reform efforts called for market oriented tools of accountability to be employed, such as outcome measures, customer satisfaction assessments and broad performance management techniques. However, there is a good deal to be done to consider how these various devices apply to public service networks.

\section{Internal Impacts on Refugee Service Organizations}

All of these factors add up to produce a variety of impacts within individual refugee service organizations. Thefacts of life in service networks add stresses as executives spend more time on boundary spanning obligations and funding issues which takes them away from the organization's primary mission, straining relationships with workers and sometimes with boards of directors. ${ }^{52}$ It is often the case that networks expect that member organizations will, as one private sector network advocate recommends, "offer the best and brightest. Put your best peopleinto these relationships." ${ }^{53}$ However, do- 
ing so frequently brings stress inside the home organization.

Even more than that, however, is the importance of the presence of leverage pressures in the networks. The fact is that the use of grants and contracts with not-for-profit is viewed in part at least as a way of leveraging greater impact from the same dollars than what could be developed in a government organization and competition for resources makes it possible to leverage more. ${ }^{54}$ That additional impact must come from the organization and its people. And because refugee service workers are so committed to their mission, they often willingly accept obligations to attend evening meetings, invitations to weekend events in the refugee and immigrant communities and emergency requests for help at virtually any time. However, there are costs to the service providers and their families for this commitment and responsiveness.

Unfortunately, however, there is often a tendency to underestimate these and other real costs relative to actual revenue that comesinto a service organization from grants and contracts in addition to the costs mentioned earlier having to do with the actual preparation of proposals and administration of grants or contracts. Failing to incorporate the investments of time and energy required for grant writing and contract administration in assessments of resource commitment for service delivery is a serious miscalculation of true cost. Similarly, assuming contributions from other units of the network that may not in reality be able to continue support at current levels let alone to enhance is a further problem. These errors may produce overestimated resources and underestimated obligations. And just as ministries and local government agencies cannot contribute funds that they do nothave, NGOs cannot provide service commitments that they cannot support without damaging their people and their organizations. These extraordinary efforts can be mounted during emergencies or for relatively limited periods, but if they continue for toolong, they will take a toll.
Even assuming that a network participant is not overextended, it is still important that the people within the organization be equipped by training and support to deal with the stresses that the network is producing. For example, as programme eligibility rules become more stringent, it is important that personnel be trained to meet those new situations in order to better serve refugee clients. It is particularly helpful if people from other parts of the network, including government units, can be trained together. Unfortunately, in organizations, both governmental and nongovernmental, that are under financial stress, training and professional development is often one of the first areas to be cut if indeed such support was ever available. Moreover, apart from training programmes, few organizations in the network provide organizational renewal support. It should be no surprise to find that burnout is a problem even among committed service providers. That accumulated stress can manifest in increased conflict within organizations as well as in more personal ways.

Of course, one of the dangers that can come from network stresses is a sense by service workers of a loss of identity. In the refugee service arena, many workers came to particular organizations because of a strong commitment to what the agency does. If the organization alters its directions or seeks to change its mission and character because of the demands of networks, there is a danger of internal conflict. The same is true if a board of trustees, believing that it should focus primarily on the demands of thenetwork, hires executives who are, orwhoare perceived tobe, more committed to the network than they are to their own organization and the people it was designed to serve. If the executive decides to focus primary attention on entrepreneurial efforts to entertain new programmes as opportunities for the organization, the message may be that the existing programmes are not important. That can be devastating to paid employees or volunteers who have worked long and hard to develop the ongoing programmes and make them work in the face of challenges. These kinds of changes are particularly difficult in refugee services where successful performance depends upon trust that takes years to build in the refugee and immigrant communities. Success also depends upon a sense of continuity and continuing service even though it is clear that the network context and the larger environment within which service networks function is turbulent.

\section{Conclusion}

To those who work in the schools, clinics, settlement offices, or legal settings, it may sometimes appear that they operate almost alone. For those who work in local NGOs providing particular types of services, it can appear that they are struggling to create and deliver services out of what is available locally to meet a great need with little assistance. From the perspective of government officials at the provincial level or in Ottawa, the challenge is to address some 25,000 new refugee arrivals each year and to provide some level of support for the service systems on which those new Canadians must depend for their settlement and integration into society. But the reality is that all of these people are participants in refugee service networks. And what each can or cannot accomplish on behalf of refugees is in very important respects related to how those service networks function.

Certainly the networks are affected by the political, economic and legal pressures in their environment. There is little question that political pressures to constrain grants of asylum and to take an approach that is heavily oriented toward enforcement complicates the tasks of both the refugees and the service providers who seek to assist them. The set of economic cutbacks at all levels and across the full range of agencies and services has placed a severe strain on those providers as well. And certainly, the possibility of significantly more complex and restrictive policies at the federal and provincial levels in a variety of social service programmes adds to the pressure on the organizations within the service networks. 
All that having been said, the mission is very much worth the effort. Surely everyone involved can agree that it is critical that the emphasis must be on how to provide the best quality services in the requisite quantity to ensure that new Canadians can build their new lives and make the kind of constructive contributions to the society that so many refugees and immigrants have before. Challenges have always brought out the very best in the kinds of people who dedicate their time and talents to refugee services.

However, in order to perform that mission in the contemporary environment, it is important to recognize that the people and the individual organizations are indeed parts of service networks, that those networks have a variety of common characteristics and those characteristics in turn have consequences. Without losing sight of one's own objectives and those of the home organization, it is important to consider those networks and their consequences in the day-to-day challenge to welcome new Canadians.

Those of us who have been in a position to learn so much from Canadian refugee service providers continue to watch and to learn as the dedicated public servants, NGO members, and individual providers meet these challenges.

\section{Notes}

1.Elinor Caplan, "Notes for an Address to the Maytree Foundation Trends in Global Migration Forum," Toronto, January 12, 2000. http://cicnet.ci.gc.ca/english/ press/speech/maytree-e.html.

2.Elinor Caplan, "Statement by Minister Elinor Caplan on Illegal Human Smuggling to Canada," August 11, 1999, http: //cicnet.ci.gc.ca/english/press/speech/ smuggle-e.html, p. 1.

3.Elinor Caplan, "Remarks to the Canadian Club," Vancouver, British Columbia, September 9, 1999, http://cicnet.ci.gc.ca/ english/ press/speech/canclub-e.html, p. 4.

4.Elinor Caplan, "Remarks to a News Conference on Year 2000 Immigration Levels," November 1,1999, http://cicnet.ci.gc.ca/ english/press/levels2000-e.html, p. 2.
5. Caplan, "Notes for an Address to the Maytree Foundation Trends in Global Migration Forum," p. 7.

6.I have dealt with these trends in comparative context for Canada, the United States and the E.U. countries in "Problems of Locus and Focus: Continuing Tensions in Refugee Policy," Education \& Society, forthcoming.

7.July 28, 1951, 189 U.N.T.S. 137.

8.January 31, 1967, 606 U.N.T.S. 267.

9.Clarkson, "Remarks to the Canadian Club," p. 2.

10."A ReluctantWelcome," Maclean's, January 4, 1993, p. 26

11."An Update of Intergovernmental Transfers 1996 to 1999," Prepared by Gary Williams and Associates, January, 1999, for the Union of British Columbia Municipalities, http://civicnet.gov.bc.ca/cutbacks/gwtrans_rpt.html

12.Citizenship and Immigration Canada, Report on Plans and Priorities 1999/2000, p.7.

13.Canadian Council for Refugees, Refugees in Canada: Canadian Refugee and $\mathrm{Hu}$ manitarian Policy 1997 to mid-1998(Montreal: Canadian Council for Refugees, 1998) p. 2.

14.See e.g., "A sanctuary for refugees or a haven for terrorists" Weighing Canada's commitments to human rights against our obligations to national security, The Globe and Mail, Monday, January 24, 2000.

15.See Netherlands Ministry of Foreign Affairs, "TheNetherlands and the Schengen Agreement." http://www.minbuza.nl/ english/policy/c_nethschengen.html and Claus Thiery, The Schengen Agreements, Centrefor International and European Law on Immigration and Asylum, University of Konstanze, Paper prepared for workshop entitled "Managing Migration in the 21st Century."http://migration.unikonstanz.de/alt/mm21/Thiery.html.

16.See Rosemary Byrne and Andrew Shacknove, "The Safe Country Notion in European Asylum Law," Harvard Human Rights Journal, 9 (Spring ) 1996, pp. 185-228.

17. "Interim Report of the Working Party on Asylum Procedures," to the 1998 Conference of the International Association of Refugee Law Judges(IARLJ), prepared by Jacek Chlebny, Judge at the Supreme Administrative Court of Poland, http:// www.irb.gc.ca/IARLJ/wp-asylum.htm.

18.U.S. Senate, Committee on the Judiciary, U.S. Immigration Law and Policy: 19521986, 100th Cong., 1st Sess. 1987.

19.For the most comprehensive picture available on the Southeast Asia refugee crisis, see Roger Winter, Terms of Refuge: The
Indochinese Exodus and the International Response (New York: Zed Books, 1998).

20.See Sale v. Haitian Centers Council, 509 U.S. 155 (1993).

21.760 F.Sup. 796 (NDCA 1991).

22. Illegal Immigration Reform and Immigrant Responsibility Act of 1996,P.L. 104208, 8 U.S.C. p. 1101, et seq.

23. Bo Cooper, "Procedures for Expedited Removal and Asylum Screening Under the Illegal Immigration Reform and Immigrant Responsibility Act of 1996," Connecticut Law Review 19 (Summer), 1997. p. 1501

24.Gerald H. Stobo, "The Canadian Refugee Determination System," Texas International Law Journal 29 (Summer), 1994, p. 383.

25.Immigration Legislative Review, Not Just Numbers: A Canadian Framework for Future Immigration (Ottawa: Minister of Public Works and Public Services Canada, 1997.

26.(Ottawa: Minister of Public Works and Government Services Canada, 1998).

27.Ibid., p. 3.

28.Building on a Strong Foundation, pp. 4142

29.See e.g. Elinor Caplan, "Notes for an Address to the Canadian Bar Association B.C. Immigration Section Refugee Symposium," Vancouver, British Columbia, November 26, 1999, http:/ / cicnet.ci.gc.ca/ english/press/speech/cha-e.html.

30.Elinor Caplan, "Notes for an Address to the Annual Meeting of the Canadian Council for Refugees," Niagra Falls, Ontario, December 3, 1999, p.5. http://cicnet.ci. gc.ca/english/press/speech/ccr-e.html.

31. See e.g. Judith R. Saidel, "Resource Interdependence: The Relationship Between State Agencies and Nonprofit Organizations" Public Administration Review, 51 (Nov/Dec 1991), pp. 543-553; "The Dynamics of Interdependence Between Public Agencies and Nonprofit Organizations" Research in Public Administration, 1994 (3), pp. 201-229.

32.H. Brinton Milward, "The Changing Character of the Public Sector," in James Perry, ed., Handbook of Public Administration, Second Edition (San Francisco: JosseyBass, 1996), p. 77.

33.John A. Bryne, "The Virtual Corporation," Business Week, February 8, 1993, p. 98.

34.H. Brinton Milward, "Implications of Contracting Out: New Roles for the Hollow State," in Patricia W. Ingraham and BarbaraS. Romzek, eds., New Paradigms for Government: Issues for the Changing Public Service (San Francisco:Jossey-Bass, 1994), p. 41. 
35.See Paul M. Tellier, Public Service 2000: A Report on Progress (Ottawa: Minister of Supply and Services, 1992); David Osborne and Ted Gaebler, Reinventing Government (New York:Plume/Penguin, 1993); Al Gore, Report of the National Performance Review, From Red Tape to Results: Creating A Government That Works Better and Costs Less (Washington, D.C.: Government Printing Office, 1993).

36.See e.g., ChristopherPollitt, "Management Techniques for the Public Sector: Pulpit and Practice," in B. Guy Peters and Donald B. Savoie, eds., Governance in a Changing Environment (Montreal \& Kingston: McGill-Queen's University Press, 1995).

37.See Donald F. Kettl, Sharing Power: Public Governance and Private Markets (Washington, D.C.: Brookings Institution, 1993).

38. Byrne, op. cit.

39.Ibid.

40.Robert Agranoff and Michael McGuire, "Big Questions in Public Network Management Research," Paper prepared for delivery at the 1999 National Public Management Research Conference, Texas A\&M University, George Bush Presidential Conference Center, December 3-4, 1999, p. 1.

41. Ibid., p. 1.
42. Ibid., p. 3.

43.H. Brinton Milward and Keith G. Provan, "Governing Networks, Managing Networks: Principles for Controlling Agents," Paper prepared for delivery at the 1999 National Public Management Research Conference, Texas A\&M University, George Bush Presidential Conference Center, December 3-4, 1999, p. 12.

44.See Saidel and Sharon Harlan, "Contracting and Patterns of Nonprofit Governance", Nonprofit Management and Leadership 8 (3), pp. 243-259.

45.Laurence J. O'Toole, Jr., "Different Public Management Implications of Structural Context in Hierarchies and Networks," in Jeff Brudney, LaurenceJ. O'Toole, and Hal Rainey, eds., Advancing Public Management: New Directions in Theory, Methods and Practice (Washington, D.C.: Georgetown University Press, 2000).

46. "In brief, network contexts increase the range of potentially manipulable variables subject to influence by public managers thus apparently enhancing the importance of management. At the same time, however, networks also increase uncertainty and decrease institutional fixedness for all actors in the setting. Managers have more levers available, but so do others." Ibid.
47.H. Brinton Milward, "Introduction to Symposium on the Hollow State: Capacity, Control, and Performance in Interorganizational Settings," Journal of Public Administration Research and Theory 6 (April 1996): 194

48. Agranoff and McGuire, op. cit., p. 18.

49.Milward, The Changing Character of the Public Sector, op. cit., p. 87.

50.Eugene Bardach and Cara Lesser, Accountability in Human Service Collaboratives For What? And To Whom? Journal of Public Administration Research and Theory 6 (April) 1996, pp. 197-224.

51.I have attempted to address these issues in Accountability and Administrative Reform: TowardConvergence and Beyond, in Peters and Savoie, op. cit.

52. See Saidel, "Contracting and Patterns of NonprovitGovernance."

53. See Byrne, op. cit. p. 98.

54.Laurence $\mathrm{O}^{\prime}$ Toole discusses a variation on the concept of leveraging, but one that is quite different from the refugee services case. "Hollowing the Infrastructure: Revolving Loan Programmes and Network Dynamics in the American States," Journal of Public Administration Research and Theory 6 (April 1996: 225 at 233-239). ב

\section{Background Information on the}

\section{Centre for Refugee Studies}

TheCentreforRefugee Studies (CRS) is an organized researchunit of York University. Founded in 1988, the Centre for Refugee Studies is successor to the Refugee Documentation Project created in 1981 for the conservation and analy sis of research documents and data collected by Operation Lifeline during the crisis of Indochinese BoatPeople. In 1991, CRS was designated as a Centre of Excellenceby the Canadian International Development Agency (CIDA).

The Centre for Refugee Studies fosters interdisciplinary and collaborative research in all of its undertakings. The efforts of CRS are focused in areas related to a comprehensiveresearch programme expanding from theoretical to institutional research. In carrying out thisresearch. CRS networks with Canadian and international development agencies and academic institutes, CRS invites scholars from abroad to participate in the research. Canadian and international students are supported by CRS to undertake field studies and conductrelated research. Joint research activities with institutions in the developing counties areunderway. CRS plays asignificantrolein an advisory capacity with Canadiangovernment and other agencies. 